\title{
Sexual dimorphism and left-right asymmetry of carapace ornamentation in Hemicytheria setosa RUNDIĆ, 2002
}

\author{
Vukica Vujić ${ }^{1}$, Ljupko Rundić ${ }^{2}$ and Tamara Karan-Žnidaršič ${ }^{3}$ \\ 1 University of Belgrade, Faculty of Biology, Department of Genetics and Evolutionary Biology, Studentski Trg 16, 11000 Belgrade, Serbia; (vukica.vujic@bio.bg.ac.rs) \\ 2 University of Belgrade, Faculty of Mining and Geology, Department of Regional Geology, Kamenička 6, 11000 Belgrade, Serbia; (ljupko.rundic@rgf.bg.ac.rs) \\ ${ }^{3}$ University of Belgrade, Faculty of Biology, Department of Morphology, Systematics and Phylogeny of Animals, Studentski Trg 16, 11000 Belgrade, Serbia; \\ (corresponding author: ktamara@bio.bg.ac.rs)
}

doi: $10.4154 / g c .2019 .07$

Article history:

Manuscript received September 13, 2018

Revised manuscript accepted January 15, 2019 Available online June 3, 2019

\begin{abstract}
In biostratigraphic research of the Upper Miocene of the Pannonian Basin System, one of the frequently detected and important ostracod genera is Hemicytheria. Among more than 20 species of this genus, Hemicytheria setosa is present in sandy facies of the Lake Pannon sediments in Serbia and Bosnia and Herzegovina. The aims of this study were to describe sexual dimorphism and differences between left and right valve morphology in Hemicytheria setosa. Landmark based geometric morphometrics is applied on the grounds of existence of the homologue pattern of the fossae and pore conuli on the valve surface of this group of ostracods. Significant differences between the sexes and between the left and right valves are detected in the present study. The obtained results indicate that applied methods and chosen landmarks could be useful in the studies of valve ornamentation-variation in fossil and recent Ostracoda.
\end{abstract}

Keywords: Shell morphology, Ostracods, Geometric morphometrics, Valve reticulation pattern, Late Miocene, Southern Pannonian Basin together with other "caspibrackish" Upper Pannonian (Late Miocene) ostracods and Rundić (2002) also mentioned that it has a relatively small and thick-shelled carapace. However, in $H$. setosa the size and shape of the reticula is different, sometimes with poorly developed second-order reticulation. This feature is not common for the genus Hemicytheria that comprises more than 20 species from the Middle - Late Miocene (SOKAČ, 1972; JIŘÍČEK, 1985; OLTEANU \& VEKUA, 1989; OLTEANU, 2011). This form represents a very abundant ostracod species within the sandy facies of the long-lived Lake Pannon (Late Miocene) (RUNDIĆ, 2006; KOVÁCS et al., 2016). Additionally, some other ostracodologists from the area of the Pannonian (POKORNÝ, 1952, 1955; SOKAČ, 1972; JIŘíČEK, 1985; PIPÍK, 2007), and Transylvanian and Dacian basins (OLTEANU \& VEKUA, 1989; OLTEANU \& JIPA, 2006; OLTEANU, 2011; KOVÁCS et al., 2016) discovered large differences in the sculpture of the carapace between the Hemicytheria species during the period from the Middle Miocene (Sarmatian) to the end of the Late Miocene (Pannonian s. lato).

Most studies come from the sediments of the ancient Lake Pannon which was a remnant of the Central Paratethyan Sea and existed during the Late Miocene (ca. 11.6 - 5.3 Ma). Apart from the studies of SOKAČ (1972), RUNDIĆ (1997, 2002), PIPÍK (2007) and OLTEANU (2011), there are no publications that have focused on the genus Hemicytheria. Also, to our best knowledge there is no geometric morphometric study applied to this genus, although geometric morphometrics is used in study of the Ostracoda (ABE et al., 1988; BALTANÁS \& GEIGER, 1998; BALTANÁS \& DANIELOPOL, 2011; MAZZINI et al., 2014; AIELLO et al., 2016; KARANOVIC et al., 2017).

The aims of this research were to describe sexual dimorphism and differences between left and right valves in carapace ornamentation of Hemicytheria setosa, using the landmark based geometric morphometrics. 


\section{GEOLOGICAL BACKGROUND}

Belgrade city area and its surroundings belongs to the southern part of the Pannonian basin (PB) that has a dynamic geological evolution through the Neogene (HARZHAUSER \& PILLER, 2007; MAROVIĆ et al., 2007). Miocene sediments were deposited discordantly over Mesozoic rocks and represent the infill of the Paratethys Sea or its successor - Lake Pannon (HARZHAUSER \& PILLER, 2007; HARZHAUSER \& MANDIC, 2008; RUNDIĆ et al., 2011).

Early to Middle Miocene sediments of the PB and its southern part (e.g. Serbia) show a transition from continental alluviallacustrine to fully marine environments (MAROVIĆ et al., 2007; PAVELIĆ \& KOVAČIĆ, 2018). Extensional tectonics reached their maximum during the Middle Miocene rifting phase (ca. 16-11.6 Ma) when marine water flooded the whole region (e.g. MATENCO \& RADIVOJEVIĆ, 2012; RADIVOJEVIĆ \& RUNDIĆ, 2016). At the Middle/Late Miocene boundary (11.6 $\mathrm{Ma})$ as a result of the tectonic uplift of the Carpathians, the PB was isolated from marine influences and the long-lived Lake Pannon formed (MAGYAR et al., 1999; TER BORGH et al., 2013; SZTANÓ et al., 2015). Seven million years later, Lake Pannon was infilled by lacustrine and fluvial-deltaic sediments derived from the surrounding orogenic belts (MAGYAR et al., 2013; RADIVOJEVIĆ \& RUNDIĆ, 2016) (Fig. 1).

The Late Miocene sediments contain numerous fossils (molluscs, ostracods, etc.) widely distributed in the Belgrade city area and its vicinity (RUNDIĆ, 1993; RUNDIĆ et al., 2011). Most of them have an endemic character and settled the littoral and sublittoral environs of the ancient Lake Pannon (MAGYAR et al., 1999; RUNDIĆ et al., 2011). Among the ostracods, large numbers of originally freshwater taxa were recognized, candonids predominantly (KRSTIĆ, 1973; RUNDIĆ, 2006). However a lot of genera show brackish and so-called the "caspibrackish" character (similar to the modern Caspian Sea). Among them, the genus Hemicytheria and its species is very important for biostratigraphic zonation of the Pannonian Stage (KRSTIĆ, 1973, 1985; RUNDIĆ, 2006; KOVÁCS et al., 2016). Generally, older low diversity ostracods from the early Pannonian expanded to the abundant taxa during the late Pannonian age. This interval is designated as the "bloom time" for many ostracods, both qualitatively and quantitatively (RUNDIĆ, 2006).

Based on the stratigraphic division of the Late Miocene Lake Pannon province as well as the biostratigraphic zonation, the Hemicytheria setosa interval corresponds to the early Pannonian age (Fig. 2). According to KRSTIĆ $(1973,1985)$ and RUNDIĆ $(1997,2006)$ this species is found in the fifth and sixth ostracod biozones (Amplocypris abscissa and Hemicytheria croatica). Its discovery suggests the sublittoral/littoral environs of Lake Pannon. Besides the studied area, Hemicytheria setosa is found in the Upper Pannonian s.str. (Late Miocene) of Serbia (e.g. Kolubara basin, Vrčin) and Bosnia and Herzegovina (north-eastern part of the Mt. Majevica) (RUNDIĆ, 1993, 2002).

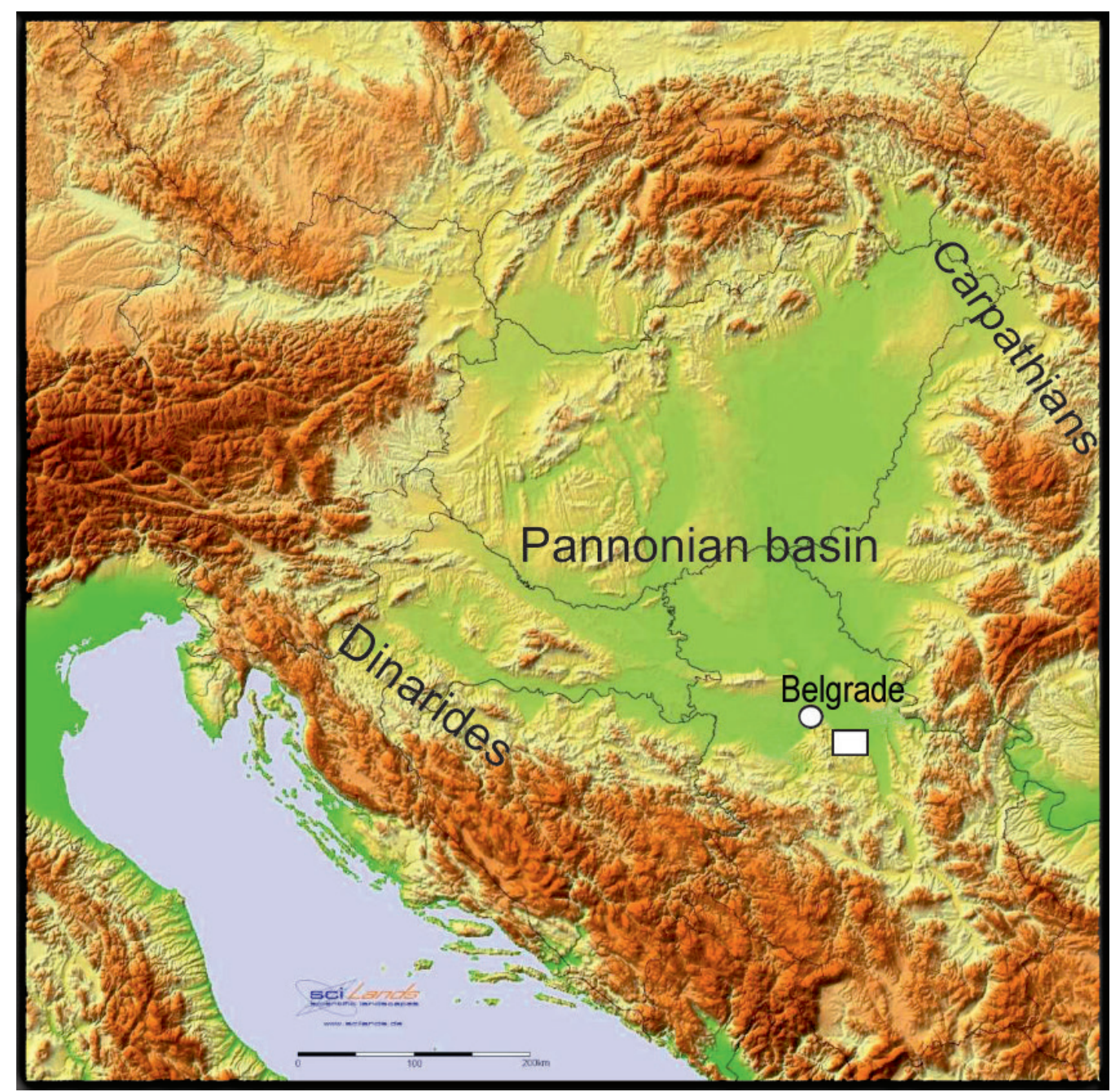

Figure 1. The Pannonian basin and its southern and eastern margins (SCILANDS, 2015). White rectangle indicates the studied area. 


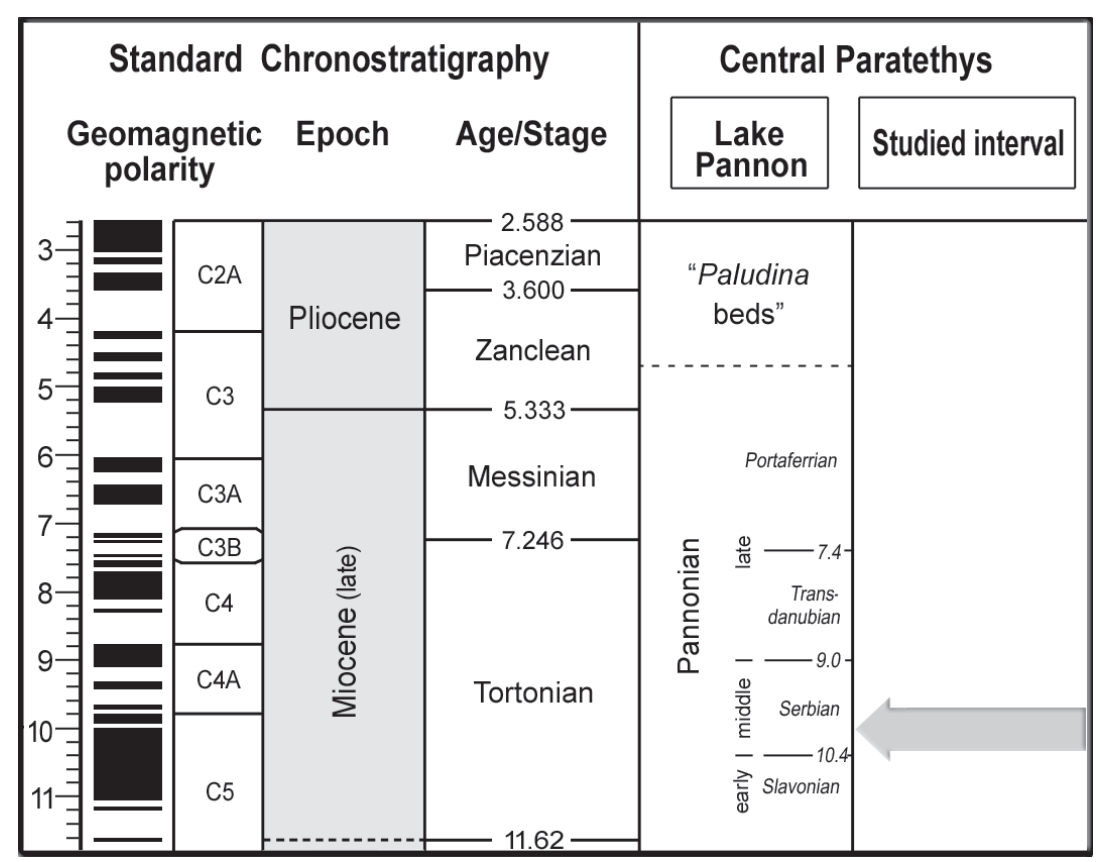

Figure 2. A chronostratigraphic chart of the Late Miocene Lake Pannon (modified after NEUBAUER et al., 2015). Gray arrow marks the position of the studied interval.

\section{MATERIALS AND METHODS}

\subsection{Locality and the studied species}

The sample for this study is taken from the sandy facies of the Lake Pannon sediments, from the left tributary of the Kokorin stream, Djurinci near Mali Požarevac, central Serbia, 44³1'51.70”N, $20^{\circ} 38^{\prime} 49.21^{\prime \prime} \mathrm{E}$ at an altitude of $187 \mathrm{~m}$ a.s.l. (see Fig. 1).

This species has a small, thick-shelled trapezoidal carapace. Convexity is considerable, highest in the anterior part. The straight or slightly arched dorsal margin descends obliquely toward the posterior part. The ventral margin is straight or slightly concave in the first third, while the anterior margin is rounded, semicircular. Posterior end perpendicular, in males posterio-ventrally extended. Margins are without denticulation. Surface reticulated. Normal pore canals arranged in the suboval fossae separated with slightly faveolate muri. In the middle of the valves, fossae are tiny and shallow. There is a clearly arched ridge in the eye part, which is continuous with the anterior rib. Ventral rib poorly developed. Marginal zone broad. Hinge holoamphidont, in the juvenile forms poorly developed. Other features are the same as the genus Hemicytheria (RUNDIĆ, 2002).

Class Ostracoda LATREILLE, 1802

Order Podocopida SARS, 1866

Superfamily Cytheroidea BAIRD, 1850

Family Hemicytheridae PURI, 1953

Subfamily Hemicytherinae PURI, 1953

Genus Hemicytheria POKORNÝ, 1955

Species Hemicytheria setosa RUNDIĆ, 2002

Synonymy:

1985 Aurila (Hemicytheria) sp. (setosa) - KRSTIĆ, Pl.14, Fig.1 1991 Hemicytheria setosa KRSTIĆ - RUNDIĆ, P1.1, Figs.1-4

1997 Hemicytheria setosa n. sp. RUNDIĆ \& KRSTIĆ - RUNDIĆ, p.66-67, P1.10 Figs.1-4

2002 Hemicytheria setosa n. sp. - RUNDIĆ, p.138-139, Pl. 1, Figs.1-6

\subsection{Material preparation and applied analyses}

The field campaign and sampling were performed during the autumn of 1992. Eight bulk sandy samples (ca. $400 \mathrm{~g}$ ) have been taken from the Kokorin stream. After the standard procedure of washing and sieving (meshes from $0.6-0.125 \mathrm{~mm}$ ) and $\mathrm{H}_{2} \mathrm{~S}_{2}$ treatment, ostracods were picked and analysed under an Olympus BH2 stereomicroscope (Faculty of Mining and Geology, University of Belgrade). Some of the samples are very rich in ostracod content (more than 350 specimens including both carapaces and valves). Those samples marked as 1/92OS and 1A/92OS contain more than 300 adult $H$. setosa specimens of both sexes. The ostracod collection is stored at Faculty of Mining and Geology, University of Belgrade.

In this study, the female and male valves were photographed on the stereomicroscope Discovery V.8 with a Zeiss camera Icc1 in AxioVision 4.6.3 software (Carl Zeiss, Jena, Germany). To compare left-right asymmetry, all photographs are flipped to the left orientation prior to the landmark placement.

To determine shape differences between the sexes, as well as differences in left (LV) and right valve (RV) morphology, ge-

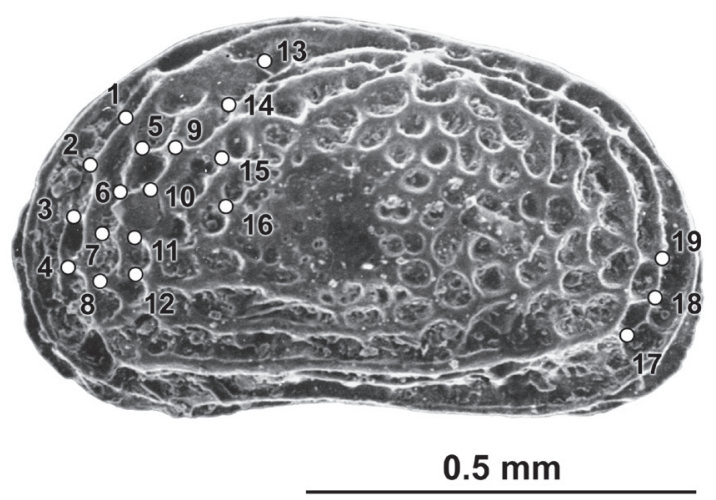

Figure 3. Position of landmarks on the carapace of $H$. setosa (female left valve SEM image modified from RUNDIĆ, 1991). 

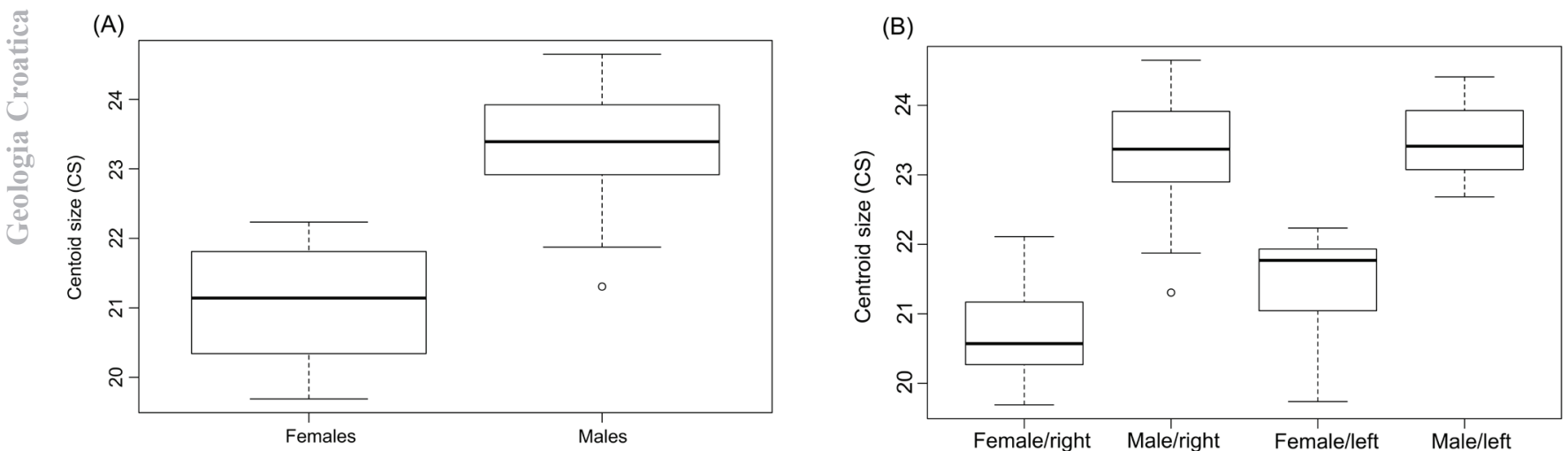

Figure 4. Differences in carapace CS between the sexes (A) and the sides of both sexes (B). The median with the first and the third quartiles is shown (in boxes), together with the range of variation and outliers.

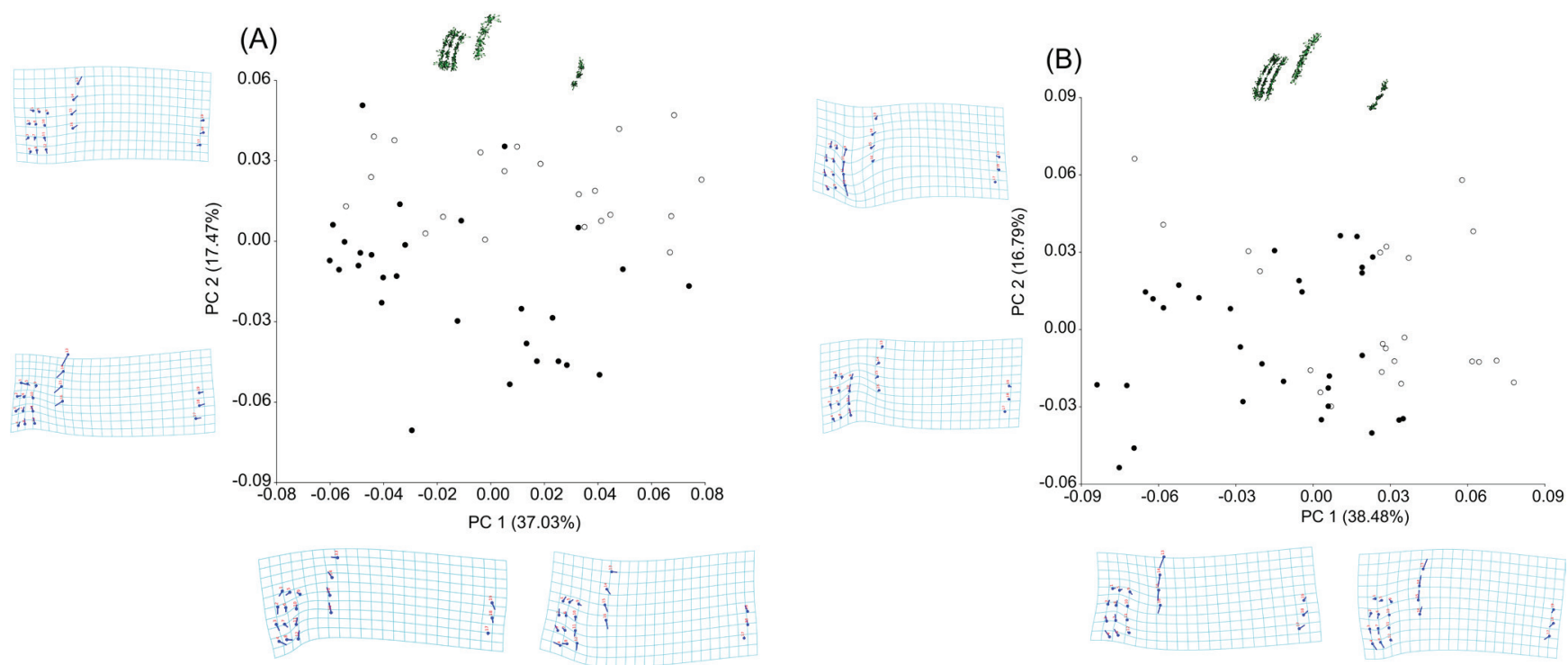

Figure 5. Principal component analyses and warp analyses in: (A) right and (B) left valves in both sexes ( $\mathrm{F}$ - white circle, $\mathrm{M}$ - black circle). The pattern of morphological variation is illustrated using the position and size of vectors which influence on a thin plate spline deformation grid.
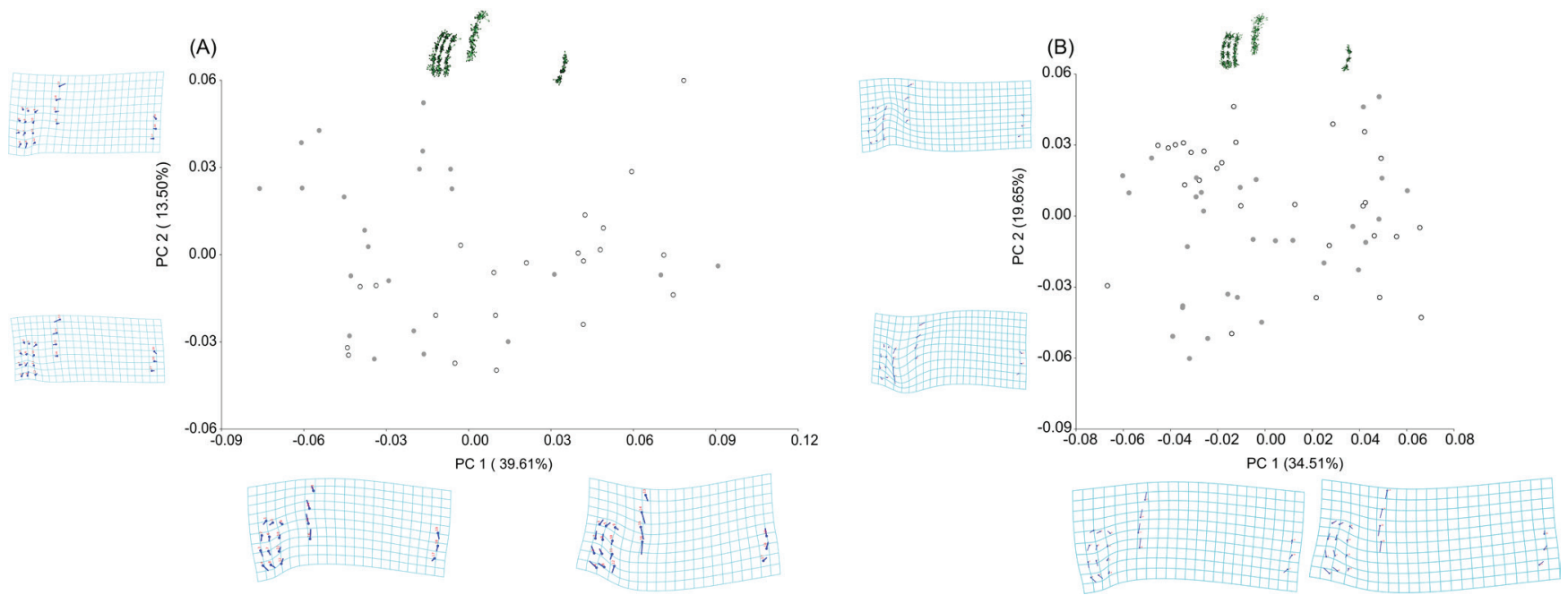

Figure 6. Principal component analyses and warp analyses in: (A) females and (B) males (left valves - grey circles, right valves - white circles). The pattern of morphological variation is illustrated using the position and size of vectors which influence on a thin plate spline deformation grid.

ometric morphometric analyses were used. In total, 19 landmarks are chosen based on the homology of the fossae in the Hemicytheridae (AL FURAIH, 1977; LIEBAU, 1977; AIELLO et al.,
2016). We placed landmarks on some of the fossal groups proposed by AIELLO et al. (2016). They are positioned on the pore conuli, recognizable as prominent ridges on the valve surface 


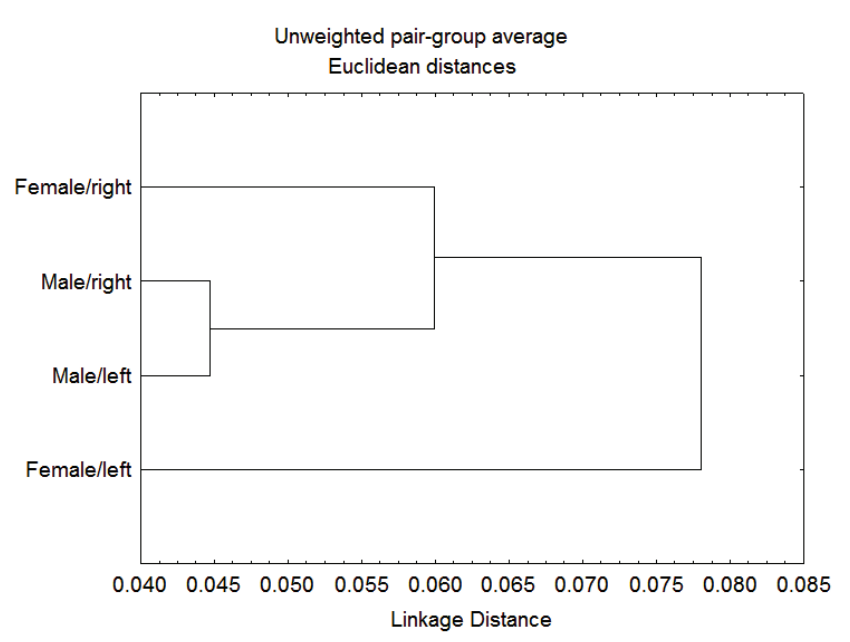

Figure 7. Valve shape similarities among left and right valves in both sexes are shown by the unweighted pair-group method using arithmetic averages (UPGMA).

(Fig. 3). Four landmarks on each of the first three series of fossae, that are parallel to the anterior margin, are placed between the fossae $(1-12)$. Also, four landmarks are set starting from the ocular riblet, running in a row that surrounds the subcentral tubercle of the valve $(13-16)$. The last three landmarks are placed between the fossae on the valve rear ridge $(17-19)$. All landmarks are locally defined and classified as Type I according to Bookstein (BOOKSTEIN, 1991; ZELDITCH et al., 2004).

The program TpsDig2 (ROHLF, 2008a) was used to place the landmarks on photographs of $21 \mathrm{LV}$ and $22 \mathrm{RV}$ of females and $28 \mathrm{LV}$ and $30 \mathrm{RV}$ of males (in total, 101 valves).

To calculate the centroid size (CS) the CoordGen6 program (SHEETS, 2003) was used. Size in geometric morphometrics is noted as the centroid size that quantifies the spread of landmarks around their centroid (KLINGENBERG, 2013). In this study, the centroid size of each specimen was determined based on the refe- rence length on each picture. Principal component analysis (PCA) and Canonical Variate Analysis (CVA) were performed in the MorphoJ program (KLINGENBERG, 2011). Also, morphological variation of the valves shape and size was analysed by Warp analysis in TpsRelw programme (ROHLF, 2008b). The warp analyses show dispersal of each landmark and its distance from the centroid in the sample, while PCA analysis exhibits total morphological variability in the sample. The shape analyses were done by Canonical Variate Analysis which was performed based on values of Procrustes coordinates and values of centroid size that is treated as the covariate in the analyses. Additionally, cluster analysis based on Procrustes distances from CVA and the unweighted pair-group method using arithmetic averages (UPGMA) was performed. All statistical analyses were done in STATISTICA 5.1 (StatSoft, 1997) and R statistical software (R Development Core Team, 2008).

\section{RESULTS}

The results of the analyses indicated that the centroid size of the valves is statistically different between the sexes $(p<0.0001$; Fig. $4 \mathrm{~A}$ ). Differences in the CS between the left and right valve of females and males separately are significant only in females (females: $p<0.0005$; males: $p<0.334$ ) (Fig. 4B). Intersexual morphological variability in valve shape and CS are shown on Fig. 5. Additionally, variability of valve shape and CS of left and right valves into the same sex are exhibited in Fig. 6.

Results of cluster analysis show that the shape of the right and left valves in males is more morphologically similar in comparison with the shape of left and right of valves in females (Fig. 7).

The spatial relationship of the fossae and pore conuli on the valve surface is different between the sexes (Fig. 8). The differences in shape are more prominent in the central and posterior part of the valves. The lateral protrusion of the valves in females is positioned further backward than in males, relative to the anterior part that does not show statistical differences in position between the sexes (Fig. 8). The posterior part shows the opposite tendency, as the posterior ridge is moved forward in the females, and backward in the males (Fig. 8).
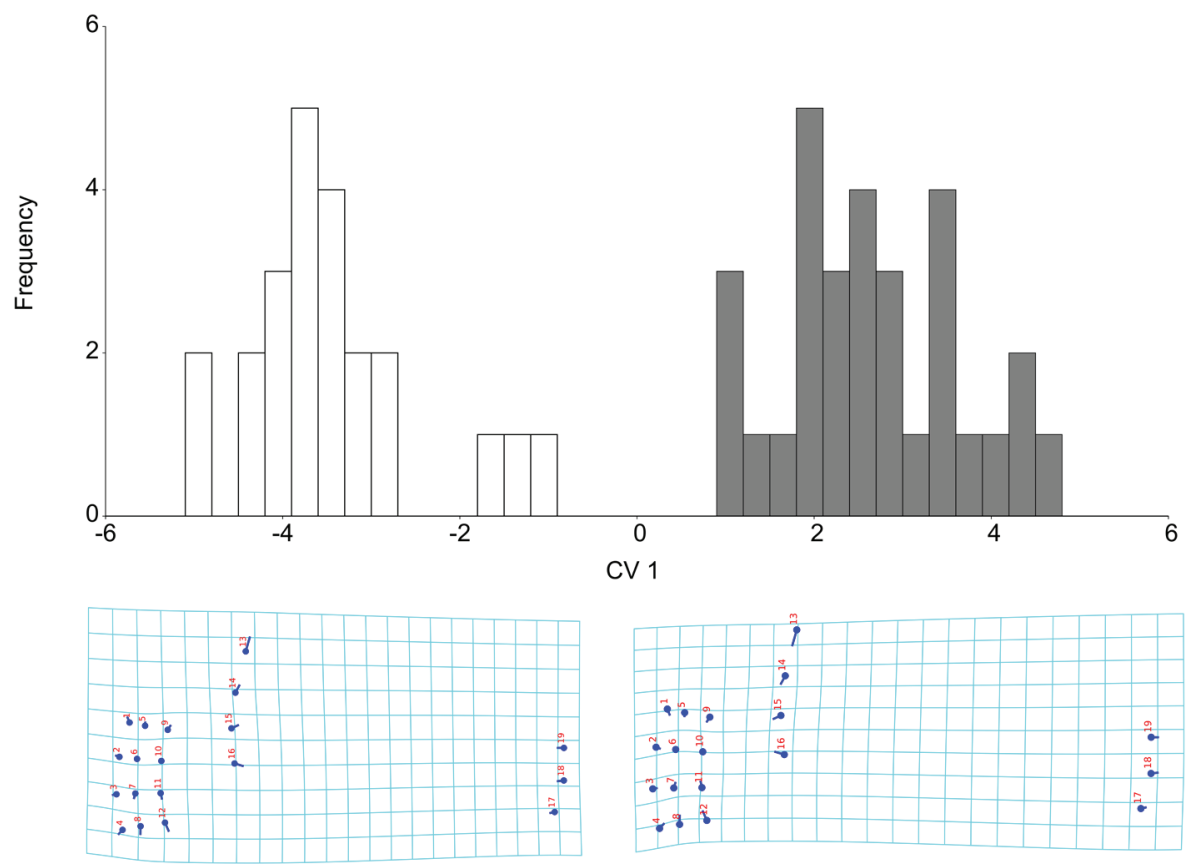

Figure 8. Intersexual carapace shape differences (white bars - females, grey bars - males). The pattern of the mentioned differences is illustrated using the position and size of vectors which influence on a thin plate spline deformation grid. 

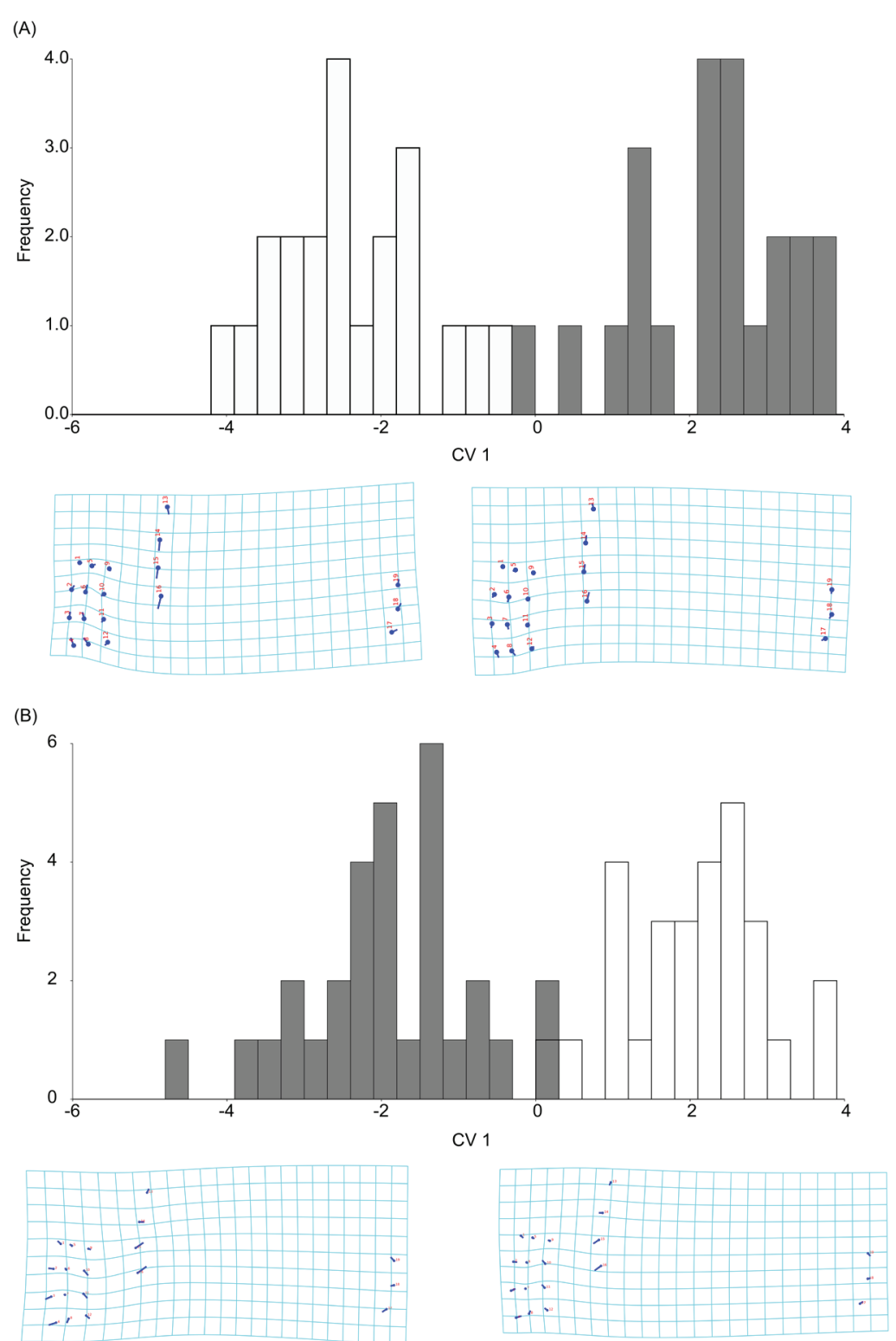

Figure 9. Carapace shape differences between left (grey bars) and right (white bars) valves in: (A) females and (B) males. The pattern of the aforementioned differences is illustrated using the position and size of vectors which influence on a thin plate spline deformation grid.

The differences in shape based on superficial ornamentation between left and right valves are detected in both sexes separately (Fig. $9 \mathrm{~A}$ and B). In females, the variation is less prominent in the anterior part. The central and posterior part of the left and right valve differ in the ornamentation pattern, as the fossae on the lateral protrusion of the left valve are placed more downward, whereas the fossae on the posterior part are more upward. The opposite tendency is noted on the right valve of females (Fig. 9 A). In males, the most conspicuous is the variation of the first anterior ridge, which is moved forward in comparison to the same ridge on the right valve. Also, the fossae on the lateral protrusion of the left valve are placed more backward, whereas the posterior ridge of the left valve is more forward in comparison with the right valve (Fig. 9 B).

\section{DISCUSSION AND CONCLUSIONS}

The valve morphology is the most crucial for palaeontological identification. Morphological variability of this trait is analyzed here in detail on an intersexual level and between left and right valves in Hemicytheria setosa, bearing in mind that there is a lot of carapace morphological variation among species within the genus Hemicytheria (e.g. SOKAČ, 1972). The results of landmark based geometric morphometric analysis that is applied, suggest significant differences are present in the carapace shape between the sexes and between the left and right valves in Hemicytheria setosa.

In relation to other forms of the genus Hemicytheria, this species shows variation in carapace sculpture. The polygonal to suboval fossae in combination with large semi-circular pits are the main characteristics that differentiate this form from others. Namely, SOKAČ (1972), RUNDIĆ (1997, 2002, 2006) and PIPÍK (2007) already mentioned there are Hemicytheria species which have three types of valve ornamentation: pitted, reticulated and smooth.

Valve shape intersexual differences are already described in cytheroids (MARTINS et al., 2017) and Hemicytheridae, as "high-doomed and oval" in females and "more rectangular" in males (BATE et al., 1981). The results of the present study show 
that the shape of the valve surface is in line with the findings of the aforementioned authors. The greatest differences between the sexes are noted in the posterior part of the valves, which are more elongated in males. That is in accordance with the findings of MARTINS et al. (2017), who concluded that males have larger posterior parts and because of a large copulatory apparatus that is located beneath this part of the carapace.

Apart from intersexual differences in carapace ornamentation, results of this study represent the first assessment of differences in carapace ornamentation between left and right sides in some cyteroid species. It is interesting to note that left-right asymmetry in size between valves was present in females, but not in males. This notion needs to be more deeply investigated in further research. Left-right asymmetry in females of $H$. setosa shows a different ornamentation pattern than in males, which adds one more characteristic to conspicuous intersexual differences. In females, the differences between sides are absent in the anterior region of the valves, whereas in the central and posterior part, placement of the fossae and pore conuli show movements in the vertical line. In males, the most differences between valves are in the anterior part, while the central and posterior valve surfaces, show differences in ornamentation along the horizontal line, that is the opposite in comparison with females.

This research is the first attempt to explore a suitable method to assess valve ornamentation-variation and to suggest the choice of landmarks which could be useful in future, more extensive investigations, on a larger interspecific sample.

\section{ACKNOWLEDGEMENT}

The results of this study are a part of Projects: No. 173025 "Evolution in Heterogeneous Environments: Adaptation Mechanisms, Biomonitoring and Conservation of Biodiversity" and No. 176015 "Geodiversity, lithostratigraphy and geological evolution of the basins of the central Balkan Peninsula and adjacent areas", approved and financed by the Ministry of Education, Science and Technological Development of the Republic of Serbia. We are very grateful to Valentina HAJEK-TADESSE and an anonymous reviewer for the valuable comments that helped to improve the manuscript. We also express our gratitude to the Editors Alisa MARTEK and Tea FLUKSI for the support provided during publication process, as well as to Julie ROBSON for the improvements of the English language quality.

\section{REFERENCES}

ABE, K., REYMENT, R.A., BOOKSTEIN, F.L., HONIGSTEIN, A., ALMOGI-LABIN, A., ROSENFELD, A. \& HERMELIN, O. (1988): Microevolution in two species of ostracods from the Santonian (Cretaceous) of Israel.- Historical Biology, 1, 303-322. doi: 10.1080/08912968809386481

AIELLO, G., BARRA, D. \& PARISI, R. (2016): Intra-and interspecific shell variability of the genus Urocythereis Ruggieri, 1950 (Ostracoda: Hemicytheridae) in the La Strea Bay (Ionian Sea, Italy).- European Journal of Taxonomy, 193, 1-35. doi: 10.5852/ejt.2016.193

AL-FURAIH, A.A. (1977): Cretaceous and Palaeocene species of the ostracod Hornibrookella from Saudi Arabia.- Palaeontology, 20/3, 483-502.

BAIRD, W. (1850): The natural history of the Britich Entomostraca.- Ray Society London, $364 \mathrm{p}$.

BALTANÁS, Á. \& DANIELOPOL, D. (2011): Geometric Morphometrics and its use in ostracod research: a short guide.- Joannea Geologie und Paläontologie, 11, 235-272.

BALTANÁS, Á. \& GEIGER, W. (1998): Intraspecific morphological variabilty: morphometry of valve outlines.- In: MARTENS, K. (ed.): Sex and Parthenogenesis. Backhuys Publishers. Rundle, S.D. \& S.J., 127-142.

BATE, R.H., WHITTAKER, J.E. \& MAYES, C.A. (1981): Marine Ostracoda from the Galapagos Islands and Equador.- Zoological Journal of the Linnean Society, 73, $1-79$.
BOOKSTEIN, F.L. (1991): Morphometric Tools for Landmark Data: Geometry and Biology.-Cambridge University Press, Cambridge. doi: 10.1017/CBO9780511573064

HARZHAUSER, M. \& PILLER, W.E. (2007): Benchmark data of a changing sea - palaeogeography, palaeobiogeography and events in the Central Paratethys during the Miocene.- Palaeogeography, Palaeoclimatology, Palaeoecology, 253, 8-31. doi: 10.1016/j.palaeo.2007.03.031

HARZHAUSER, M. \& MANDIC, O. (2008): Neogene lake systems of Central and South-Eastern Europe: faunal diversity, gradients and interrelations.- Palaeogeography, Palaeoclimatology, Palaeoecology, 260, 417-434. doi: 10.1016/j.palaeo.2007.12.013

JIŘÍČEK R. (1985): Die ostracoden des Pannonien.- In: PAPP, A., JAMBOR, A. \& STEININGER, F.F. (eds.): Chronostratigraphie und Neostratotypen, VII, M-6, Pannonien (Slavonien und Serbien). Akadémiai Kiadó, Budapest, 348-408.

KARANOVIC, I., LAVTIŽAR, V. \& DJURAKIC, M. (2017): A complete survey of normal pores on a smooth shell ostracod (Crustacea): Landmark-based versus outline geometric morphometrics.- Journal of Morphology, 278, 1091-1104. doi: 10.1002/ jmor.20696

KOVÁCS, E., MAGYAR, I., SZTANÓ, O. \& PIPÍK, R. (2016): Pannonian ostracods from the southwestern Transylvanian basin.- Geologia Croatica, 69/2, 213-229. doi: $10.4154 /$ gc. 2016.16

KLINGENBERG, C.P. (2013): Visualizations in geometric morphometrics: how to read and how to make graphs showing shape changes.- Hystrix, 24, 15-24.

KLINGENBERG, C.P. (2011): MorphoJ: an integrated software package for geometric morphometrics.- Molecular Ecology Resources, 11, 353-357. doi: 10.1111/j.1755-0998.2010.02924.x

KRSTIĆ, N. (1973): Biostratigraphy of the congerian beds in the Belgrade region on the basis of Ostracoda with the description of the species of the genus Amplocypris. Institute for Geological and Mining Explorations and Investigation of Nuclear and Other Minerals Raw Materias, Monographs, Vol. 4, 208 p. (in Serbian, with an English Abstract)

KRSTIĆ, N. (1985): Ostracoden im Pannonien der Umbegung von Belgrade.- In: PAPP, A. et al. (eds.): Chronostratigraphie und Neostratotypen, Miozän M6, Pannonien. Akadémiai Kiadó, Budapest, 103-143.

LATREILLE, P.A. (1802): Histoire naturelle générale et particulière des Crustacés et des insectes.- Tome 3. Familles naturelles des genres. Paris: F. Dufart, xii + 467 p.

LIEBAU, A. (1977): Carapace ornamentation of the Ostracoda Cytheracea: principles of evolution and functional significance.- Aspects of ecology and zoogeography of Recent and Fossil Ostracoda, 107-120.

MAGYAR, I., GEARY, D.H. \& MÜLLER, P. (1999): Paleogeographic evolution of the Late Miocene Lake Pannon in Central Europe.- Palaeogeography, Palaeoclimatology, Palaeoecology, 147, 151-167. doi: 10.1016/S0031-0182(98)00155-2

MAGYAR, I., RADIVOJEVIĆ, D., SZTANÓ, O, SYNAK, R., UJSZÁSZI, K. \& PÓCSIK, M. (2013): Progradation of the paleo-Danube shelf margin across the Pannonian Basin during the Late Miocene and Early Pliocene.- Global and Planetary Change, 103, 168-173. doi: 10.1016/j.gloplacha.2012.06.007

MAROVIĆ, M., TOLJIĆ, M., RUNDIĆ, LJ. \& MILIVOJEVIĆ, J. (2007): Neoalpine tectonics of Serbia.- Serbian Geological Society, Ser. Monographie, Belgrade, $88 \mathrm{p}$.

MARTINS, M.J.F., HUNT, G., LOCKWOOD, R., SWADDLE, J.P. \& HORNE, D.J. (2017): Correlation between investment in sexual traits and valve sexual dimorphism in Cyprideis species (Ostracoda).- PloS One, 12/7, e0177791. doi: 10.1371/ journal.pone.0177791

MATENCO, L. \& RADIVOJEVIĆ, D. (2012): On the formation and evolution of the Pannonian Basin: Constraints derived from the structure of the junction area between the Carpathians and Dinarides.- Tectonics, 31, TC6007, 18-49. doi: 10.1029/2012TC003206

MAZZINI, I., GLIOZZI, E., ROSSETI, G. \& PIERI, V. (2014): The Ilyocypris puzzle: A multidisciplinary approach to the study of phenotypic variability.- International Review of Hydrobiology, 99/6, 395-408. doi: 10.1002/iroh.201301729

NEUBAUER, T.A., HARZHAUSER, M., KROH, A., GEORGOPOULOU, E. \& MANDIC, O. (2015): A gastropod-based biogeographic scheme for the European Neogene freshwater systems.- Earth-Science Reviews, 143, 98-116. doi: 10.1016/j. earscirev.2015.01.010

OLTEANU, R. (2011): Atlas of the Pannonian and Pontian ostracods from the eastern area of the Pannonian basin.- Geo-Eco-Marina, 17, 135-177.

OLTEANU R. \& VEKUA D. (1989): Quelques considérations sur les genres Tyrrhenocythere (RUGGIERI, 1955) et Hemicytheria (POKORNÝ, 1955) (Ostracoda, Crustacea) du Néogène supérieur de la Paratéthys.- Geobios, 22, 65-79. doi: 10.1016/S0016-6995(89)80089-0

OLTEANU, R. \& JIPA, D. (2006): Dacian basin environmental evolution during Upper Neogene within the Paratethys domain.- Geo-Eco-Marina, 12, 91-105.

PAVELIĆ, D. \& KOVAČIĆ, M. (2018): Sedimentology and stratigraphy of the Neogene rift-type North Croatian Basin (Pannonian Basin System, Croatia): A review.- Marine and Petroleum Geology, 91, 455-469. doi: 10.1016/j.marpetgeo.2018.01.026 
PIPÍK, R. (2007): Phylogeny, palaeoecology, and invasion of non-marine waters by the late Miocene hemicyhterid ostracod Tyrrhenocythere from Lake Pannon.- Acta Palaeontologica Polonica, 52/2, 351-368.

POKORNÝ, V. (1952): The Ostracods of the so-called Basal Horizon of the Subglobosa beds at Hodonín (Pliocene, Inner Alpine Basin, Czechoslovakia) [in Czech with Russian and English abstracts].- Sborník Ústředního Ústavu Geologického, 19, 229-396.

POKORNÝ, V. (1955): Contribution to the morphology and taxonomy of the subfamily Hemicytherinae Puri 1953 (Crustacea, Ostracoda).- Acta Universitatis Carolinae, Geologica 3, 3-35.

PURI, H.S. (1953): Contribution to the study of the Miocene of the Florida Panhandle.The Florida Geological Survey, Geological Bulletin, 36/3, 217-345.

R DEVELOPMENT CORE TEAM (2008): Rversion 3.5.1 (2018-07-02): a language and environment for statistical computing. R Foundation for Statistical Computing, Vienna, Austria. Available online at: http://www.R-project.org [Verified 26 November 2018]

RADIVOJEVIĆ, D. \& RUNDIĆ, LJ. (2016): Synrift and postrift Miocene sediments of northern Banat, Serbia.- Underground Mining, 28, 39-60. doi: 10.5937/ podrad1628039R

ROHLF, F.J. (2008a): TpsDig, Version 2.12. Ecology and evolution, SUNY at Stony Brook: Stony Brook, NY, USA.

ROHLF, F.J. (2008b): TpsRelw. Version 1.46. Ecology and Evolution, SUNY at Stony Brook: Stony Brook, NY, USA.

RUGGIERI, G. (1955): Tyrrhenocythere, a new ostracode genus from the Mediterranean.- Journal of Paleontology, 29, 698-699.

RUNDIĆ, LJ. (1991): Upper Pannonian ostracods from the vicinity of Mali Požarevac.Annales Géologiques de la Pénninsule Balkanique, 55/1, 213-220.

RUNDIĆ, LJ. (1993): Biostratigrafija gornjeg panona severoistočne Majevice (Bosna) na osnovu ostrakoda [Biostratigraphy of the Upper Pannonian of northeastern Majevica, Bosnia based on ostracodes].- Proceedings of Geoinstitute, 28, 63-80.

RUNDIĆ, LJ. (1997): Biostratigrafija kaspibrakičnog neogena Kolubarskog basena [Biostratigraphy of the Caspibrackish Neogene of Kolubara basin - in Croatian, with an English Abstract].- Unpubl. PhD Thesis, Faculty of Mining and Geology, University of Belgrade, $128 \mathrm{p}$.
RUNDIĆ, LJ. (2002): Some species of the genus Hemicytheria, Pokorny (Ostracoda, Crustacea) from the Upper Miocene of Serbia.- Annales Géologiques de la Pénninsule Balkanique, 64, 137-151. doi: 10.2298/GABP0264137R

RUNDIĆ, LJ. (2006): Late Miocene ostracodes of Serbia: morphologic and palaeoenvironmental considerations.- Annales Géologiques de la Pénninsule Balkanique, 67, 89-100. doi: 10.2298/GABP0667089R

RUNDIĆ, LJ., GANIĆ, M., KNEŽEVIĆ, S. \& SOLIMAN, A. (2011): Upper Miocene Pannonian sediments from Belgrade (Serbia): new evidence and paleoenvironmental considerations.- Geologica Carpathica, 62/3, 267-278. doi: 10.2478/v10096011-0021-z

SARS, G.O. (1866): Oversigt af norges marine ostracoder--Forhandlinger i Videnskabsselskabet i Christiania, $130 \mathrm{p}$.

SCILANDS (2015): The shaded hypsometric maps of Hungary, Slovakia, Slovenia, Croatia, Serbia, Bosnia-Herzegovina, Montenegro.- Available online at: http:// www.scilands.de/

SHEETS, H.D. (2003): 'IMP: Integrated Morphometrics Package.' (Department of Physics, Canisius College: Buffalo, NY, USA.) Available online http://www3.canisius. edu/ sheets/morphsoft.html [Verified 25 November 2018]

SOKAČ, A. (1963): Panonska fauna ostrakoda Donjeg Selišta jugozapadno od Gline [Pannonian fauna of Ostracoda of Donje Selište southwest of Glina - in Croatian].- Geološki vjesnik, 15/2, 391-401.

SOKAČ, A. (1972): Pannonian and Pontian Ostracode fauna of Mt. Medvednica.- Palaeontologia Jugoslavica, 11, 1-140, JAZU, Zagreb.

STATSOFT, Inc. (1997): 'STATISTICA'(StatSoft: Tulsa, OK, USA.)

SZTANÓ, O., SEBE, K., CSILLAG, G. \& MAGYAR, I. (2015): Turbidites as indicators of paleotopography, Upper Miocene Lake Pannon, Western Mecsek Mountains (Hungary).-Geologica Carpathica, 66/4, 331-344. doi: 10.1515/geoca-2015-0029

TER BORGH, M., VASILIEV, I., STOICA, M., KNEŽEVIĆ, S., MATENCO, L., KRIJGSMAN, W., RUNDIĆ, LJ. \& CLOETHING, S. (2013): The isolation of the Pannonian basin (Central Paratethys): new constraints from magneto- and biostratigraphy.- Global and Planetary Change, 103, 99-118. doi: 10.1016/j.gloplacha.2012.10.001

ZELDITCH, M.L., SWIDERSKI, D.L., SHEETS, H.D. \& FINK, W.L. (2004): Geometric Morphometrics for Biologists: A Primer. Elsevier, San Diego. 